\title{
Domov a jiná místa/ne-místa formování kulturních identit
}

\author{
Home and the Other Places/Non-Places Shaping the Cultural \\ Identities
}

\section{Csaba Szaló}

ABSTRACT The first part of the article follows the recent anthropological critique of the widely held assumption that links people to territorial roots. In this sense, cultural identities have to be mediated by particular places, nevertheless these places does not necessarily have to have character of local cultural communities. Current conditions of deterritorialization are producing cultural identities that link people to homes and homelands that often have no territorial base. The following section makes the outlined critique deeper by claiming that cultural identities are also mediated by places that do not have the character of homes or even deterritorialized homelands. The theoretical precondition of this claim is explicated by a classificatory model that distinguishes between four types of life in motion - exile, immigration, pilgrimage, and vagabondage - and by this means establishes an analytical fairness between the perspectives of sedentarism and nomadism.

KEY WORDS home, identity, nomadism, place, transnationalism

Aadam Aziz se jednoho jarního rána rozhodl, že se už nikdy více nepokloní žádnému bohu ani člověku. Bylo to v roce 1915, poté co ztroskotal jeho pokus o ranní modlitbu: jak se skláněl k modlitebnímu koberci, narazil nosem na trs trávy. Tehdy si uvědomil marnost své vlastní snahy předstírat sám před sebou, že se po jeho návratu domů nic nezměnilo. Jeho modlitba byla neustále narušována vzpomínkami na Heidelberg. Nemohl nepřemýšlet o svých heidelberských přátelích, o společných debatách, které je rozdělovaly. Jako čerstvě vystudovaný medik se po pěti letech vrátil do Kašmíru a onoho rána už si musel přiznat, že jeho domov není, jaký byl. Neboli i když vše bylo jako dřív, Aadam se na svět díval jinýma očima. Všiml si, že krásné údolí, v němž stojí jeho rodný dům, je vlastně úzké - uvědomil si uzavřenost tohoto světa. A musel se vyrovnat také s tím, že jeho návrat a jeho vzdělání nevzbudily v jeho domácím prostředí žádné nadšení, spíše naopak. Uvědomil si, že nemůže dále ignorovat svou vlastní proměnu. Co však vědět nemohl, co ovšem nám čtenářům autor Dětí půlnoci (1995) Salman Rushdie naznačuje, je to, že jeho rozhodnutí už se nikdy nemodlit v něm zanechalo prázdnotu. Nemohl se modlit k Bohu, v jehož existenci zároveň nemohl úplně nevěřit. Vrátil se domů na místo, kde po svém návratu už nikdy nebyl doma.

Salman Rushdie ve své knize představuje vzorec pohybu, ve kterém se návrat domů ukazuje být jednou z podob nekonečného putování na nová mista. To, co se nám obvykle jeví jako ukončení dočasné podoby pohybu, získává nomádskou povahu putování bez konce.

Sociální studia. Fakulta sociálních studií Masarykovy univerzity, 1/2006. S. 145-160. ISSN 1214-813X. 
Návrat domů pritom obvykle chápeme jako projev cíleného a dočasného pohybu - specifického pohybu směrujícího na místo původu. Rushdieho př́iběh odkrývá symbolickou sílu normativní představy, podle které by skutečný návrat domů měl být nejenom návratem na místo původu, ale také znovunastolením původních praktik, zkušeností a vztahů domorodého života. Jako čtenáři rozumíme situaci Aadama Azize, protože jsme schopni rekonstruovat, proč je jeho návrat domů problematický. Takové rekonstrukce jsme schopni proto, že intersubjektivně sdílíme normativní představu o návratu domů. Rozumíme tomu, co Aadam Aziz po svém návratu domů našel, protože jsme s to si představit, co hledal.

Pokud kladu v tomto textu důraz na interpretaci, ve které se návrat domů ukazuje být jednou z podob nekonečného putování na nová mista, nechci tím tvrdit, že ve skutečnosti žádný návrat neexistuje a že existuje jenom putování. Nechci jít ani tou stezkou uvažování, podle které měli v minulosti naši předkové ještě to štěstí zakoušet skutečné návraty domů, avšak podmínky současnosti už stejnou zkušenost neumožňují, a zůstává nám tedy úděl nekonečného putování. Na následujících stránkách se budu snažit spiše o kulturně sociologickou reflexi (implicitně sdílených) symbolických předpokladů a normativních představ, které jsou zakódovány $\mathrm{v}$ soudobých podobách života $\mathrm{v}$ pohybu. Rekonstrukce sémantických polí, $\mathrm{v}$ nichž pristěhovalectví, vyhnanství, putování a potulování získávají smysl, nabývá důležitosti díky tomu, že jsou tyto kategorie pohybu propojeny s ideologicky zabarvenými kategoriemi domova, kultury, původu, zakořeněnosti a svobody. $V$ mnoha prípadech si ani neuvědomujeme, že naše pojetí toho, co znamená být přistěhovalcem či uprchlíkem, je zakotveno v implicitně sdílených formách vědění o tom, co znamená být na určitém místě doma a co znamená pocházet odněkud a odjinud.

Teoretické perspektivy, které se $\mathrm{v}$ současnosti objevily ve společenských vědách, a to především v antropologii, přinesly nový pohled na vztah lidí a míst a přispěly tím k reflexi procesu teritorializace a deteritorializace kulturní identity (Appadurai 1988, 1997c, 1997a, 1997b; Clifford 1988, 1997b, 1997a; Gupta a Ferguson 1997; Malkki 1997, 1995; Rosaldo 1993; Hannerz 1992, 1998). Tato reflexe se ubírala cestou zpochybnění metaforické představy „zakořeněnosti“ lidí v jejich vlastním místě pobytu. Onu perspektivu můžeme rekonstruovat následovně: $v$ současnosti jsou vztahy lidí $\mathrm{k}$ domovu a kultuře jiné a složitější než v minulosti, a to $\mathrm{z}$ toho důvodu, že stále více lidí žije své životy v podmínkách pohybu. V obecném povědomí i na poli věd je sdílená metaforická představa zakořeněnosti zpochybňována fenoménem toho, že naši současnost charakteristizují lidé, kteří jsou nositeli deteritorializované podoby kulturní identity. Lidé se $\mathrm{v}$ tomto smyslu identifikují především s deteritorializovanými podobami vlastní kultury a domova. Jinými slovy mnozí současníci vynalézají domovy a vlastní kulturu nehledě na nepřitomnost vlastního územního základu této kultury. Klíčovou roli zde hrají vzpomínky a představy míst, na nichž tito lidé aktuálně nepobývají.

V tomto textu sleduji dvojí cíl. Na jedné straně v souladu se současnou kulturně-antropologickou kritikou obecně přijaté představy zakořeněnosti ukazuji, že společenství, ke kterým nás naše kulturní identity vážou, jsou sice zprostředkována místy, ale ta nemusí mít nutně charakter lokálních kultur. Neboli poukazuji na to, že kulturní identity formují naše vztahy k sobě samým a druhým tím, že zvýznamňují naši př́slušnost $\mathrm{k}$ určitým společenstvím, která však nemusí být nutně společenstvími žité prítomnosti každodennosti. Na straně druhé se zabývám kritikou zakořeněnosti, podle níž jsou pro naši současnost charakterističtí lidé, kteří se identifikují s de- 
teritorializovanými podobami domova. Tuto kritiku prohlubuji tezí, podle níž nemusí mít místa formující kulturní identity nutně podobu (ani deteritorializovaného) domova. Nedomyšleným důsledkem zdůrazňování důležitosti identifikace s deteritorializovanými podobami domova je totiž reprodukce normativní představy, podle níž je původním, normálním a přirozeným místem formování kulturních identit místo mající charakter domova.

\section{Domov}

Situace popisovaná Rushdiem zřetelně kontrastuje s normativní představou o návratu domů. Tato normativní představa je konkrétní krystalizací abstraktního strukturálního vztahu lidí a míst, př́tomnou v obecném povědomí každodennosti, v politickém diskurzu a v neposlední řadě i na poli vědeckého zkoumání. Podle této představy tvoří místo formování kulturní identity lidí jejich domov. Domov je specifickým místem, jež spoluvytváŕí identitu lidí, protože je nalezištěm jejich vzpomínek. „Každý z nás“ se narodil a vyrostl někde, a musí proto odněkud pocházet: měl by být někde zakořeněný. Je to právě tato představa, jež nás normativně vede $\mathrm{k}$ tomu, abychom o svých identitách uvažovali a vyprávěli v symbolickém řádu původu, předků a kořenů. ${ }^{1}$ Kromě toho, že je domov představován jako místo původu naší jedinečnosti a sounáležitosti, je také koncipován jako místo formování solidarity. V tomto smyslu svazuje své obyvatele do historického společenství soudržnosti prostřednictvím každodenní žité př́tomnosti na určitém místě: skutečné vztahy solidarity mohou existovat pouze mezi lidmi sdílejícími stejný každodenní životní prostor, stejné místo. Tato představa v sobě navíc obsahuje normativní předpoklad, podle nějž mezi lidmi sdílejícími žitou přítomnost určitého místa vztahy soudržnosti existovat musí.

Vzhledem k míŕe rozšíření a implicitnímu charakteru této nereflektované perspektivy v mnoha diskurzech obecného povědomí i vědy se ukazuje analýza jejích př́íznaků jako nezbytný úkol teoretizující sociologie. V následující části textu se proto podívám na jeden z těchto př́źznaků - na obecně príijímané pojetí domova jako místa návratu, tak jak ho můžeme nalézt v textu Alfreda Schütze -, aby bylo následně možné pojetí domova dekonstruovat.

Alfred Schütz ve své stati Der Heimkehrer (2004) nastiňuje dva odlišné typy zkušenosti začleňování se do místní společnosti: zkušenost přistěhovalců a zkušenost navrátilcủ. Přistěhovalci se snaží usadit v místní společnosti, do níž nikdy nepatřili. Právě proto v jejich zkušenostech vynikají odlišnosti mezi novým a starým světem: dennodenně si uvědomují, že se pohybují v cizím prostředí, jež je plné nejrůznějších nástrah. Přistěhovalci orientují své jednání na projekt budování nové existence. Horizontem jejich zkušeností se tak stává budoucnost. Navrátilci (např́ílad váleční veteráni nebo exulanti) se naopak po dlouhé době vrací do svého dobře známého prostředí, v ideálně typickém př́padě do svého rodiště (Schütz 2004). Jejich zkušenost začleňování/znovuzačleňování do místní společností se zakládá na předpokladu, že do této společnosti patří a že její prostředí důvěrně znají. Navrátilci proto své jednání obvykle orientují na vzpomínky. Horizontem interpretace jejich současných zkušeností je jejich vlastní minulost.

Obecně o symbolickém řádu a diskurzivní strategii formování identity prostřednictvím normativních představ a mýtů zakořeněnosti a původu viz Anderson (1991), Bell (2003), Clifford (1988: 338), Deleuze a Gauttari (1992), Foucault (1998), Malkii (1997), Smith (1986). 
Zkušenosti navrátilců jsou blízké mýtické podobě pojetí domova, jež lze označit za „místo návratu“. Domov je v tomto případě pojímán jako místo, odkud člověk vyráží na svou cestu a kam se z této cesty vrací. Domov je tedy místem, kam bychom se rádi vrátili tehdy, když jsme ho předtím opustili. Zkušenosti přistěhovalců jsou naopak spřízněné $s$ utopickým způsobem pojetí domova. Domov z jejich perspektivy je spíše místo, na něž se orientuje jejich projekt vytváření nového domova, je to „konečné místo“. Jinak řečeno, „domov jako cíl projektu“ odkazuje k projektu vybudování představovaného místa, budoucího domova. ${ }^{2}$

Domov je v mytickém i utopickém pojetí považovány za centrální bod koordinační soustavy, pomocí níž se orientujeme ve světě. Ideologický potenciál symbolické moci domova spočívá $\mathrm{v}$ tom, že může být souběžně interpretován $\mathrm{v}$ podobě nacionalisticky pojaté vlasti i v podobě lokálně pojatého bydliště blízkých. Takto interpretovaný domov umožňuje symbolické propojení významů rodiny, sousedství a politického prostoru státu. Toto propojení je umožněno tím, že domov je symbolickým objektem, který souběžně zastupuje jak (a) místa pobytu, jako jsou napríílad pokoje, zahrady, města, tak (b) symbolické atributy místního způsobu života, jimiž jsou přátelé, rodiče, hudba, jídlo, jazyky a zvyky.

Odlišení dvou typů zkušenosti domova odhaluje, že diskurzivní propojení místa pobytu a symbolických atributů místního způsobu života nemusí být nutně realizováno v dimenzi minulosti. Zkušenosti přistěhovalců a jejich utopické pojetí domova v podobě „konečného místa“ ukazují, že domov je symbolickým objektem, jenž sehrává rozhodující roli také při formování kulturních identit orientovaných do budoucnosti. ${ }^{3}$ Navzdory této skutečnosti př́tomné $\mathrm{v}$ obecném povědomí každodennosti, $\mathrm{v}$ politickém diskurzu a v neposlední řadě také na poli vědeckého zkoumání je domov pojímán v dimenzi minulosti: pojetí domova jako místa návratu je upřednostňováno před pojetím domova jako cíle projektu. Domov je vztahován především ke zkušenosti trvalé, žité prítomnosti na určitém mistě, respektive ke zkušenosti odcizení v př́padě toho, že lidé své domovy ztratili (Mallett 2004, Ahmed 1999). Upřednostňováním zkušenosti krize plynoucí z opuštění domova je posilována nostalgická perspektiva těch, kteř́ toto místo opustili. ${ }^{4}$ Pojetí „domova jako místa návratu“ tím získává pozici, jež budí dojem přirozenosti. Posiluje se také etnizovaný diskurz, v němž může být skutečným domovem pouze místo, odkud pocházíme.

2 Tyto analyticky odlišené podoby pojetí domova se $\mathrm{v}$ sociální realitě nutně nevážou $\mathrm{k}$ jednotlivým typům aktérů. Není nutné, aby byl domov jako cíl projektu vlastní pouze přistěhovalcům, a podobně ani metaforu domova jako místa návratu nemusejí sdílet pouze navrátilci. Přistěhovalci obvykle nereflektivně sdílí souběžně jak utopické, tak mytické pojetí, ve smyslu nového a starého domova. Podobně pojetí domova jako cíle projektu mohou sdílet také navrátilci snící o modernizaci svého domova, nebo může být toto pojetí součástí místního radikálního politického diskurzu jako součást budovatelských vizí. Domov jako cíl projektu může mít dokonce podobu projektu návratu, jehož cílem bude znovunastolení ztraceného domova.

3 Dobrým příkladem projektu budování domova jsou národní hnutí. „Nacionalizující nacionalismus“ má např́klad charakteristiku projektu „dobudování“ vlastního národního státu, který v současnosti ještě není „dostatečně“ národní (Brubaker 1996).

$4 \quad$ Specifická je v tomto smyslu perspektiva Andersona (1994), který ukazuje, jak mohou přistěhovalci pojímat svůj domov v diskurzu nostalgie po místě, které nikdy nesdíleli a které nikdy nezakoušeli. 
Z hlediska propojení místa pobytu a symbolických atributů místního způsobu života jsou klíčové drobné metonymie domova - jídlo, hudba, rodiče a podobné symbolické objekty odkazující do minulosti, obvykle do období dětství. Domov se ukazuje jako místo, kam člověk od narození patřil, a proto patří i dnes - ukazuje se jako centrální místo zakotvenosti osobní identity. ${ }^{5}$ Nicméně již zmíněný výklad deteritorializace kulturní identity ukazuje, že lidé nemusí na tomto místě (trvale) žít. K vytvoření sounáležitosti stačí, aby po tomto imaginárním místě a po kulturních praktikách odehrávajících se v něm toužili.

Drobné metonymie domova evokují zkušenost důvěry a blízkosti. Rutinní, každodenní charakter domácího života vytváŕí prostř̌edí, jež důvěrně známe, konstituuje ono místo, kde nejsou problematizovány ani cíle, ani prostředky jednání. $\mathrm{V}$ tomto prostředí není třeba znovu a znovu definovat situace a hledat vhodné způsoby jednání. I zde můžeme spatřit rozdíl mezi představou, jež takové místo důvěry a blízkosti připouští pouze $\mathrm{v}$ místě našeho původu, a představou, jež počítá $s$ možnostmi vytvoření takového místa někde jinde než v místě našeho původu. Navrátilec v místě návratu už není cizincem v cizím prostředí, nemusí být ve střehu, nemusí neustále odhadovat, co si myslí druzí. Stejně tak nemusí hledět s nejistotou do budoucnosti, jelikož o tom, jak jeho osud dopadne, nerozhoduje pouze jeho jednání. Doma má „přece“ svět jasně vypočitatelný řád: navrátilec se může spolehnout na to, že ví, co si druzí myslí, rozumí jim do té míry, že ani nemusí dopovědět větu (Schütz 2004). Rozlišení pojetí domova jako místa návratu a domova jako cíle projektu nám umožňuje si uvědomit, že domov jako místo důvěry a intimity můžeme vytvořit i prostřednictvím našeho jednání orientovaného do budoucnosti. Místo důvěry a intimity tedy nemůžeme zredukovat na místo návratu.

Nicméně jak ukazuje zkušenost navrátilců stejně jako přistěhovalců, doma můžeme být pouze na určitém místě. Domov se vždy váže k jednomu konkrétnímu místu. To, že se představa domova zakládá na zkušenostech určitého místa, můžeme vysvětlit odkazem na charakter domácích vztahů. Sdílení určitého místa pobytu je klíčovým předpokladem existence vztahů důvěry a blízkosti. Domácí druhý se jednak objevuje v jeho celosti, v tělesnosti svého jednání, jednak se mezi obyvateli stejného domova vytváŕí společný, sdílený svět interpretací. Podobně jako pro mě domácí druhý není abstrakcí, také já nejsem pouhou abstrakcí pro něj. Jde o klíčovou charakteristiku domova, jež umožňuje navázání „čistého vztahu my“ (Schutz a Luckmann 1973).

V tomto př́padě je však důležitá reflexe idealizace místních vztahů tváří v tvář. Přestože se vztahy tváří v tváŕ zakládají na blízkosti ve smyslu časoprostorové přítomnosti, nemusejí mít vždy podobu blízkosti ve smyslu intimity, prátelství a soudržnosti. Vztahy tváří v tvář lze charakterizovat spiše různými typy blízkosti, anonymity či dokonce nevraživosti. Představy domova však veškeré místní a prostorově blízké vztahy zobrazují v podobě vztahů soudržnosti. Je přitom např́íklad jasné, že navzdory sdílení tváŕí v tvář vztahů $\mathrm{s}$ lidmi v metru je náš vztah $\mathrm{k}$ nim zcela jiné povahy než jak je tomu $\mathrm{v}$ př́padě vztahů $\mathrm{v}$ rámci společného nedělního

Domácnost, domov rodiny se v diskurzu nacionalismu stává právě místem, ve kterém se uchovávají „autentické“ kulturní praktiky a lokální identity. Nacionalismus ve svém pojetí vlasti využívá představu domova jako jediného místa, kde může být člověk skutečně sám sebou. Sounáležitost $\mathrm{s}$ tímto místem je pak vytvářena a legitimizována prolnutím diskurzů národní historie a osobní biografie. 
oběda $\mathrm{v}$ rodinném kruhu. (Idealizaci srdečnosti rodinných obědů můžeme $\mathrm{v}$ této souvislosti ponechat stranou.) Klíčové tedy je, že v diskurzu navrátilců získává jízda místním metrem kvalitu oběda $\mathrm{v}$ domácím, rodinném kruhu.

Idealizaci domácích tváří v tvář vztahů lze podrobněji vysvětlit pomocí Schützovy teorie (2004) potenciálu znovunastolení blízkého charakteru vztahu, kterou tento autor formuloval pro objasnění situace navrátilců. Pokud se podíváme blíže na tváří v tvář vztahy vznikající v prostředí domova, všimneme si, že podmínka časoprostorové přítomnosti není vždy splňována. Situace je spíše taková, že se tyto vztahy konstituují jako série institucionalizovaných situací vyplývajících ze vzájemné přítomnosti. Permanentní prítomnost a permanentní sdílení místa není ve skutečnosti předpokladem intimního charakteru tváří v tvář vztahů. Předpokladem navázání intimních vztahů je opakování situací, které umožňují znovunastolení blizkosti vztahu: tyto situace umožňují, abychom pokračovali v interakci „tam, kde jsme minule skončili“. Ono „minule“ se přitom mohlo odehrát před několika dny, ale také před několika lety. Ve skutečnosti se tedy přátelství, manželství nebo vztahy navázané v mateřské školce nezakládají na předpokladu permanentní př́tomnosti, i když charakter těchto vztahů, nebo dokonce jejich absenci, lze zakoušet v podobě ,jsme/byli jsme stále spolu“.

Pojetí ,domova jako místa návratu“ předpokládá tedy samozřejmost znovunastolení blízkosti vztahů, kdežto pojetí „,domova jako místa projektu“ počítá s možností nastolení blízkosti vztahů v budoucnosti. V uvedeném rozlišení lze spatřit zásadní symbolický rozdíl mezi mytickou podobou interpretace změny jako obnovy a mezi utopickým pojetím zdůrazňujícím vytvoření něčeho nového. Součástí obou forem pojetí domova je přitom normativní důraz na tváří v tvář vztahy, a tím také na sdílení každodenního světa. V pozadí této prèedstavy stojí zkušenost, podle níž se blízkost vztahů nezakládá na těchto vztazích samotných, ale na sdílení každodenního světa (Berger a Luckmann 1996). Co to přesněji znamená? Nejde pouze o to, že jsem s druhými na stejném místě. Ono bytí-na-stejném-místě je důležité právě proto, že místo a jeho sdílení něco umožňuje: sdílet věci kolem nás, určité praktiky, prostředky a cíle, starosti a radosti. Jinak řečeno, sdílení místa umožňuje sdílet referenční rámce jednání, interpretace a emoce - umožňuje sdílet svět: jeho minulost v podobě vzpomínek a jeho budoucnost v podobě anticipací naplněných strachem a nadějí. Sdílení místa tak vede také k možnosti sdílení kulturní identity.

Z hlediska výše analyzovaných představ domova je zásadní, že lidé sdílející domov si rozumí, a to přesto, že spolu dennodenně nekomunikují. Může tomu tak být proto, že život na stejném mistě zaručuje podle těchto představ možnost disponovat sdílenou strukturou reference a relevance. Jak představa znovunastolení vztahů blízkosti z minulosti, tak představa nastolení vztahů blízkosti v budoucnosti předpokládají, že domov spočívá ve sdílené každodennosti, v prožitku př́tomnosti na stejném místě: sdílení kulturní identity znamená bud' sdílení danosti zakořeněnosti $\mathrm{v}$ určitém místě, nebo usilování o zakořenění $\mathrm{v}$ určitém místě ve smyslu životního projektu.

Dosud jsem se snažil ukázat, že nárok diskurzů, jež mytickou představu domova esencializují a pokládají ho za opravdovou a skutečnou podobu domova, je falešným nárokem, jelikož v souladu s mytickou představou vytěsňuje zkušenosti přistěhovalců a ignoruje relevanci představ domova jako cíle projektu. V následující části textu se pokusím jít o krok dál a poukázat na meze obou výše analyzovaných pojetí domovů. Budu se pokoušet argumentovat tím, 
že sdílení kulturní identity nemusí nutně předpokládat sdílení každodenního života na stejném místě a že představa zakořeněnosti - jak ve své mytické, tak ve své utopické formě - vytěsňuje alternativní zkušenosti sdílení kulturní identity.

\section{Podoby života $v$ pohybu}

Vztah lidí a místa pojatý jako zakořeněnost identity v místě pobytu je jednodimenzionální, jelikož místo formování kulturní identity uchopuje výhradně v podobě nostalgicky vnímaného domova. U Augého (1995: 78) je tato představa přítomna např́klad v metafoře, podle níž jsou místa, která nenesou ,historické“ významy a nerozvíjí péči o kulturní identitu, ve skutečnosti ne-místy. Prostory letišt', nemocnic, hypermarketů, hotelů, továren či chudinských předměstí nejsou podle této logiky skutečnými místy. Není náhoda, že se z této perspektivy instituce modernity a především soudobé podoby života v pohybu jeví jako destruktivní síly, které ničí skutečná místní společenství a skutečné kulturní identity (Morley a Robins 1995, Bauman 1999, Giddens 1990, Meyrowitz 1985).

I z hlediska výše zmíněných výkladů lze vidět, že pojem, „život v pohybu“ neodkazuje pouze $\mathrm{k}$ jednoduchému, fyzickému přesouvání lidí mezi různými místy. Život v pohybu je metaforou, jejíž analytická síla spočívá právě v tom, že kromě samotného premístění odkazuje zároveň $\mathrm{k}$ dalším dvěma jevům s přemístěním spojeným. Život v pohybu na jedné straně odkazuje k sociálním a kulturním proměnám, které jsou procesem přemístění generovány. Na straně druhé odkazuje ke specifickým formám zkušenosti, čili k intersubjektivně sdílenému prožívání pohybu mezi místy a k proměnám vznikajícím v důsledku onoho pohybu. $\mathrm{V}$ tomto smyslu jsou jak samotné přemístění a přemístěním generované proměny, tak sdílené interpretace těchto procesů konstitutivní součástí života v pohybu.

Pohyb lidí mezi různými místy je tedy neodlučitelně spojený s událostmi proměny. Samotné plynutí času zapříčiňuje, že identita ve smyslu sebe-pojetí jednotlivců je formována v procesu vyrovnávání se s proměnou jak samotného člověka, tak jeho společenského prostředí (srov. Ricoeur 1992). Nové zkušenosti generované proměnou, nové interpretace našich vzpomínek ve světle těchto nových zkušeností, to vše způsobuje, že naše sebe-pojetí nevyjadřuje stejnost v čase, ale je dílem diskurzivních praktik udržujících kontinuitu v proudu permanentní proměny. Kdybychom však při tematizaci otázek formování identity zdůrazňovali pouze snahu o udržování kontinuity, nepodali bychom ucelený obraz tohoto procesu. Vedle praktik udržujících kontinuitu v kontextu proměňujícího se světa hrají při formování identity zásadní roli také praktiky utvářející proměnu. Poukazují přitom jak k usilování o proměnu sebe-samého, tak k usilování o proměnu světa.

Abychom mohli dešifrovat, kdo jsme, nepotřebujeme vědět pouze to, kým jsme byli v minulosti. Potřebujeme vědět také to, kým už nejsme. Shromažd'ování dokumentů, fotografií, příběhů naší minulosti neslouží pouze k tomu, abychom si s jejich pomocí připomínali kontinuitu mezi tím, kým jsme byli v minulosti a kým jsme v současnosti. Tyto prostředky vzpomínání nám totiž umožňují formulovat také odlišnosti, změnu: umožňují vyjádřit rozdíl mezí tím, kým jsme byli a kým jsme ted'. Kromě vědomí odlišnosti, jež se artikuluje vzhledem k minulosti, tvoří součást usilování o proměnu také dimenze budoucnosti. Naši identitu, ono kým jsme, můžeme dešifrovat nejenom ve světle toho, kým už nejsme, ale také ve světle toho, kým chceme být. 
Výše nastíněný vztah mezi formováním identity a času se objevuje také v případě formování našich vztahů k proměňujícím se místům. Z hlediska různých podob životů v pohybu je zásadní připomenout, že místa utvářející naši kulturní identitu nemusí být pojímána pouze jako místa udržování kontinuity. Domov, dílna, kavárna, galerie, náměstí, modlitebna, park, louka či stadion nejsou pouze místem krystalizace sdílené minulosti. Jsou zároveň místy, jež se stávají objektem našeho usilování o proměnu. Naše domovy a jiná „naše“ místa nejsou pouze skládkou minulosti - jsou také místy utváření budoucnosti. Sdílené zkušenosti, jež proměnu těchto míst zvýznamňují výhradně z hlediska představy eroze identit zakořeněných v minulosti a jež zdůrazňují atributy kontinuity, můžeme považovat za mytické. Naopak sdílené zkušenosti, které nahlíží na proměnu těchto míst výhradně z hlediska představy osvobozující budoucnosti a které zdůrazňují atributy kontrolovatelné proměny, můžeme pokládat za utopické.

Různé podoby života v pohybu se v současnosti staly formativní, intersubjektivně sdílenou zkušeností stovek milionů lidí. Zkušenost být přistěhovalcem, uprchlíkem, přesídlencem, navrátilcem, transmigrantem atd. je stejně tak zásadním prvkem současnosti, jako zkušenost zakořeněného, skrze národní identitu a práci integrovaného života. O analytickou klasifikaci různých podob života $\mathrm{v}$ pohybu se pokouším pomocí následující tabulky, jež podoby života $\mathrm{v}$ pohybu třídí na jedné straně z perspektivy interpretace proměny, kterou život v podmínkách pohybu přináší, na straně druhé z perspektivy vztahování se k pohybu a místu.

\begin{tabular}{|c|c|}
\hline Vyhnanství & Putování \\
\hline Přistěhovalectví & Potulování \\
\hline
\end{tabular}

Typy života $\vee$ pohybu

(a) Vyhnanství jako typ života $\mathrm{v}$ pohybu se zakládá na perspektivě usazenosti, která klade důraz na přirozenost a normalitu trvalé žité př́itomnosti na určitém místě. Právě z tohoto důvodu se objevuje vyhnanství jako anomálie, jako stav vynuceného a dočasného pohybu. Vyhnanství je symbolicky zvýznamňováno představou návratu, kolem níž krystalizuje mytická interpretace proměn zdůrazňující kontinuitu s minulostí. (b) Přistěhovalectví jako typ života v pohybu se také zakládá na perspektivě usazenosti. Přemístění se i z této perspektivy ukazuje jako vynucená a dočasná událost. Na rozdíl od vyhnanství je však pro přistěhování charakteristická utopická interpretace proměn, jež protože je otevřena budoucnosti, vyjadřuje naději v projekt budování nového domova. (c) Putování je typem života v pohybu, který vystupuje ze symbolického řádu usazenosti a svou nomádskou perspektivou klade důraz na bezprostřednost pohybu. Přemístění a proměny, jež z něj vyplývají, se v této podobě zkušenosti neobjevují jako anomálie, nýbrž jako normální a permanentní součásti života. Putování přitom zůstává v řádu mytické interpretace proměn, jelikož požadavek návratu a nostalgický důraz na kontinuitu s minulostí jsou zásadními znaky tohoto typu života v pohybu. V tomto př́padě však na rozdíl od vyhnanství nejde o představu definitivního návratu na místo žité přítomnosti, z důvodu bezprostřednosti pohybu můžeme mluvit spíše o souběžnosti příchodů a návratů na specifická, identitu formující místa. (d) Potulování je typem života v pohybu, 
který v souladu se svou nomádskou perspektivou oslavuje bezprostřednost pohybu. Pro tento typ je ústřední představa dobrodružství, jež artikuluje utopické podoby prožívání jak samotného přemístění, tak proměn, aniž by tato otevřenost budoucnosti musela mít podobu projektu.

Nastíněné typy můžeme chápat jako metafory výkladových systémů, které se snaží o uchopení soudobých fenoménů pohybu a z nich vyplývajících proměn. Vyhnanství je metaforou, jež pohyb naplňuje významem $\mathrm{v}$ běžném myšlení každodennosti a $\mathrm{v}$ dominantních diskurzech médií, politiky a vědy. Přes pluralitu výše zmíněných podob života v pohybu zobrazují tyto diskurzy sociální realitu a pohyb jednostranně z hlediska usazených (Augé 1995; Malkki 1995, 1997). Přistěhovalectví je klíčovou metaforou klasického sociologického pohledu již od dob působení Chicagské školy. Tento výkladový systém interpretuje pohyb jako přesídlení a pojímá ho z hlediska řešení problému, jak integrovat lidi, kteří byli ze svých původních domovů vykořeněni (Heisler 2000, Castles a Davidson 2000). Putování se jako metafora objevuje v soudobých sociálně a kulturně antropologických výkladech, jež se snaží o zpochybnění předešlých dvou pojetí pohybu. Klade se zde důraz na to, že reflexe současných transnacionálních sociálních polí a soudobých transmigrantů - lidí žijících svůj život v podmínkách permanentního překračování hranic a pobývajících souběžně na více místech, jež jsou pro jejich kulturní identity konstitutivní - by měla vést k rekonceptualizaci fenoménu migrace (Bash a kol. 1994, Kearney 1995, Faist 2000, Brettell 2000). Potulování je metaforou postmoderní sociologie a filosofie. Tato metafora na jedné straně zdůrazňuje soudobou relevanci těch forem života $v$ pohybu, které existují v modu dobrovolného nebo vynuceného dobrodružství, na straně druhé se snaží o reinterpretaci usazených forem života z perspektivy nomádství (Maffesoli 1996a, 1996b, 2000; Deleuze a Guattari 1992).

Koncepty putování a potulování představované $\mathrm{v}$ následující části textu na příkladech transnacionálních kultur, respektive nových kmenů, jsou z našeho hlediska zajímavé proto, že se jedná o projevy takových forem života v pohybu, které nejsou vázány na místa ve smyslu moderního pojetí domova jako centra. Ukazují, že kulturní identity mohou odkazovat k soudržnému společenství, lokalizovatelnému na určitém místě, že však vztah k tomuto místu nemusí mít charakter permanentní žité prítomnosti.

\section{Putování a potulování}

Představa různorodosti kultur př́tomná v obecném povědomí každodennosti, v politickém diskurzu a na poli vědeckého zkoumání rozumí kulturou takové odlišitelné celky významů a interpretačních soustav, které můžeme identifikovat, protože jsou lokalizovatelné. Každá kultura má podle této perspektivy své misto či řečeno naopak: kultura neexistuje bez umístění. Podle této představy má dokonce každý člověk své vlastní místo, jelikož patř́ k určité/jedné kultuře.

Tato obecně rozšířená představa kultury a kulturní identity předpokládá, že se kultura jako místní interpretační soustava reprodukuje a předává dalším lidem v každodenních vztazích tváří $\mathrm{v}$ tvář. Tedy že kultura je $\mathrm{v}$ podstatě kulturou místních lidí usazených na určitém místě, kde se dennodenně setkávají a komunikují. Jak ale poukazuje Hannerz $(1992,1998)$, základní definiční charakteristiky kultury, tj. existence symbolických interakcí a sociálních vztahů mezi určitým souborem lidí, předpokládají lokální charakter a místní zakořeněnost pouze za určité historické podmínky. 
Čím více budeme s to přijmout existenci a „normalitu“ trans-lokálních sociálních vztahů a interakcí, tím více budeme schopni odmítnout představu nevyhnutelnosti místní zakotvenosti kultur (Gupta a Ferguson 1997, Hannerz 1992). To, že sociální vztahy a symbolické interakce přesahují hranice lokalit, není typickým rysem pouze naší doby. V současnosti je však už evidentní, že kromě teritorializovaných kultur existujících v podobě národních (tj. trans-regionálních), regionálních a lokálních soustav sociálních vztahů a symbolických interakcí (vytvářejících identity, jež prostředkují identifikaci s těmito „místy“), můžeme pozorovat také prítomnost a rozvoj de-teritorializovaných kultur (Appadurai 1997a). Tyto deteritorializované kultury existují v podobě významových struktur, které jsou sdílené v trans-lokálně (tj. transnacionálně a globálně) rozpínajících se sítích symbolických interakcí a sociálních vztahů.

Typickými př́iklady oné podoby života $\mathrm{v}$ pohybu, které jsem výše klasifikoval jako putování, jsou deteritorializované kultury transnacionálních sítí. Představují je především globální profesní sítě (jako např́íklad transnacionální kultury byrokratů, podnikatelů, diplomatů, hudebníků, lékařů, novinářù) a transnacionální sítě přistěhovalců, které se utvářejí napříč státními hranicemi. V této souvislosti je třeba rozlišovat mezi transnacionálními kulturami budovanými zdola a transnacionálními kulturami budovanými shora (Guarnizo a Smith 1998, Guarnizo 2001). Druhý typ kultur je udržován díky působení národních států, mezinárodních organizací a globálních korporací. Naopak transnacionální kultury budované zdola jsou udržovány neformálními sociálními sítěmi přistěhovalců (Bash a kol. 1994, Glick Schiller a Fouron 2001). Brettell (2003) poukazuje na to, že tyto dvě formy transnacionalismu existují paralelně a vzájemně se posilují. Na jedné straně se např́iklad portugalské státní instituce už několik desetiletí aktivně snaží udržet loajalitu svých občanů pracujících v zahraničí. Na straně druhé udržují samotní portugalští emigranti vztahy se svými původními lokálními společenstvími v portugalských vesnicích a městech. Kromě toho, že domů posílají peníze svým př́íbuzným, rozmohl se také trend kupování či budování nových domů v „rodných“ lokalitách.

O transnacionální kultuře můžeme tedy mluvit tehdy, pokud jsou lidé, kteří do této kultury patř́í, kteří se s ní identifikují a participují v ní jak v rovině vztahů př́slušností, tak v rovině sociálních interakcí, v určitém modu pohybu - v modu putování. Přesněji řečeno, pokud tito lidé pravidelně (ročně, měsičně, týdně) podnikají cesty do mist, kde se vyskytují př́islušníci téže transnacionální kultury, tj. pokud na určitých místech nachází lidi, s nimiž mohou vstupovat do symbolických interakcí a udržovat s nimi vztahy na základě sdílených kódů a představ.

Je podstatné, že transnacionální kultury se nezakládají pouze na intersubjektivně sdíleném vědění a interpretačních rámcích, ale předpokládají realizaci symbolických interakcí a existenci sítě sociálních vztahů mezi príslušníky těchto kultur. Právě proto se zde znovu objevuje podmínka prítomnosti na určitém místě, a to přesto, že je tato prítomnost pouze dočasná.

Sdílení prítomnosti na určitém místě, nutnost setkávání a soustředěnost na interakci jsou klíčové také pro další modus života v pohybu - pro modus potulování. Jestliže fenomén putování bylo možno nalézt $\mathrm{v}$ transnacionálních kulturách, fenomén potulování nám přibližuje sociologie nových kmenů, tj. sociologie sociálních sítí založených na spř́zněnosti (Maffesoli 1996a). Metafora „nových kmenů“ vyjadřuje, že symbolické skupinové interakce sehrávají při formování kulturních identit a samotných soudržných společenstev zásadní roli. Myšlení ovlivněné metaforou „,nových kmenü“ se snaží o vykročení z duality individualizovaného jednotlivce na jedné straně a abstraktní antropomorfizované představy trŕdy, masy, národa, etnické skupiny či 
lidu na straně druhé. Je to vykročení směrem $\mathrm{k}$ analýze dynamiky sociálna ve smyslu sítí, hnutí a „neformálních skupin“, které však nejsou chápány jako derivativní prvky či živly parazitující na větších, formálně organizovaných společenských institucích.

Metafora nových kmenů má vyjádřit soudržnost, jež je výsledkem sdílení symbolů, ne-každodenních míst a ideálů. Nejde však o abstraktní, pomyslné sdílení symbolů, míst a ideálů, ale o sdílení emocionálních zkušeností bezprostřední interakce, jež přesahuje individuální identitu. Může jít např́íklad o extatické fandovství v průběhu sportovních událostí, sdílení atmosféry v nočním klubu, společné prožívání koncertu, účast na demonstraci nebo na společné modlitbě. Jinak řečeno, nové kmeny nejsou sdružení zakládaná racionální smlouvou mezi autonomními jedinci - být součástí sítě spř́izněnosti vyžaduje opuštění logiky individualizace jednotlivců. Jsme-li součástí kmene, opouštíme svou individuální identitu a stáváme se součástí něčeho, co nás přesahuje. Soudržnost těchto sítí spřízněnosti nevzniká na základě sdílení dlouhodobého projektu, který by směřoval do budoucnosti (jako $\mathrm{v}$ př́ípadě asociací typických pro modernitu), nýbrž ze sdílení konkrétní př́ítomnosti. Je to soudržnost odvozená ze současnosti a zůstávající v ní. Právě díky tomuto rysu jsou nové kmeny dobrým př́íladem dočasnosti a bytostné nestability vztahů soudržnosti.

Sociologie nových kmenů vychází z reflexe specifického charakteru přistěhovalecké soudržnosti, jež je jako vynucená forma soudržnosti charakteristická pro dnešní urbánní svět megalopolí (Brettell 2000, Massey a kol. 1998). To, že se současná velkoměsta plní přistěhovalci, vede ke vzniku městských prostor, jež jsou poskládané z mnohosti malých ostrůvků a oddělených území. Tyto „městské vesnice“ (Gans 1962), které vytvářejí přistěhovalci, však nejsou místem idylické soudržnosti tzv. pospolitostní každodennosti, jak to předpokládá moderní představa domova. Zahrnují v sobě spíše nejistotu a mnohdy až kruté mezilidské vztahy. Vztahy zakotvené $\mathrm{v}$ žité prítomnosti a ve sdíleném místě tedy nedisponují nutně idylickým charakterem domova. Městské vesnice ukazují, že vztahy k bližním nemusí mít charakter pohody a vzájemné úcty. Tyto městské prostory rozmanitosti stojí také v opozici k moderní představě města jako místa svobody a racionálně založených vztahů. Město je podle této představy společností, jež je formována svobodnými jednotlivci zapojenými do racionálně založených smluvních vztahů. Skutečnost současných megalopolí jako Sao Paolo, Káhira, Bombaj nebo Los Angeles ukazuje jiný obraz: mozaiku oddělených území propojených vnitřními vztahy vzájemné závislosti. Jak představy individualismu, tak podmínky soužití autonomních jednotlivců jsou $\mathrm{v}$ těchto městských enklávách přepisovány podmínkami závislosti a představami tribalismu. Nový tribalismus je v těchto velkoměstech reprodukován na každodenní bázi, jelikož lokální sítě spř́zněnosti jsou, kromě záruky soudržnosti, také důležitou, ne-li jedinou možností sociální kontroly.

Podmínky potulování jako jedné $\mathrm{z}$ forem života $\mathrm{v}$ pohybu, jak ho reprezentují soudobé přistěhovalecké kultury, mohou být modelem i pro další typy života $v$ nejednoznačnosti a v nejistotě. Jde totiž o podmínky života $\mathrm{v}$ pohybu, které nejsou charakteristické pouze pro naši současnost. Byly prítomné v každé epoše modernity, kde však byly považovány bud' za deviantní, nebo za přechodné. Život v podmínkách nejistoty, jehož klíčovou charakteristikou je nejistota mnohdy vyplývající z nelegálního statusu, je zkušeností milionů přistěhovalců žijících na předměstích megalopolí. Zkušenosti potulujicich se přistěhovalců představují onu nejednoznačnost, jež je pro modernitu typická a jež v jejich př́padě znamená relativizaci 
významu spojeného s vlastnictvím cestovního pasu a připsání určitého občanství (May 1999). Zakoušení nejistot spojených s potulováním relativizuje také jednoznačnost rozdělení obyvatel určitého místa na občany a ne-občany státu a zpochybňuje pozici státu jako arbitra identity. Tato forma života $\mathrm{v}$ pohybu jasně ukazuje, že identitní kategorie používané a přidělované státními úrúady jsou nejednoznačné. Namísto $\mathrm{v}$ oficiálních prostorech administrace a státních diskurzů musí přistěhovalci v megalopolích své „nomádské občanství“ (May 1999) realizovat v prostoru neidylické každodennosti, tj. v prostoru plném nejednoznačností a těžkostí. Jinými slovy přistěhovalci nemohou svou identitu zakládat na uznání státem, na oficiálním dokumentu, musí proto svou identitu zakotvit $\mathrm{v}$ dynamickém, proměnlivém a nejistém prostoru mocenských vztahů předměstí.

Metafora nových kmenů však neodkazuje pouze k podmínkám závislosti jedinců na proměnlivém a nevypočitatelném prostoru vnějších vztahů. $V$ případě, že na tribalismus pohlížíme z perspektivy moderního individualismu, bude se nám jevit pouze jako nedostatek osobní svobody. Prostory současných městských enkláv však ukazují, že nový tribalismus a jeho podoby závislosti vytváŕejí i takové kulturní identity, jež se nevážou $\mathrm{k}$ „domácímu“ místu sdílené každodennosti, ale k místům periodického proživání emočně založených vztahů a vášní. Tato rozpolcenost nového tribalismu - svazující závislost na proměnlivém světě na jedné straně a teplo/vřelost vášní v sítích spř́zněnosti na straně druhé - je charakteristická také pro ten typ nových kmenů, které nejsou založeny na místní př́ítomnosti v megalopolích, nýbrž na „symbolickém teritoriu“, tj. na symbolicky zprostředkovaných ostrůvcích prítomnosti (Maffesoli 1996a: 127).

Nové kmeny existují vždy paralelně s masou, jež je rovněž důležitým prvkem současných velkoměst. Masa představuje všezahrnující sílu moderní formy racionalizované sociální organizace, nové kmeny na straně druhé představují konkrétní krystalizaci sociálna v podobě emočních komunit. Masu vytváří komunikační média, industriální ekonomika a politická moc, a to prosazováním sdílených symbolů, které jsou však vesměs abstraktní, jelikož se netýkají každodenní dynamiky sociální reality (jako např́klad symboly ideologií, historizovaných forem kolektivní paměti). ${ }^{6} \mathrm{Na}$ rozdíl od mas vznikají nové kmeny $\mathrm{v}$ prostoru rychlých a krátkých kontaktů každodennosti, nebo dokonce $\mathrm{v}$ čistě symbolickém prostoru vkusu a zájmů (Hannerz 1980). Se stejnou rychlostí, s níž nové kmeny vznikají, mohou také zanikat. Právě proto je současnost vyznačovaná existencí nových kmenů označována za období nomádství ve smyslu potulováni se jednotlivců mezi kmenovými společenstvími, přsskakování mezi různými profesními, ideologickými a afektivními sítěmi spř́zněnosti (Bauman 1993).

Maffesoli (2002) pomocí metafory nomádství zdůrazňuje nejednoznačný charakter života $\mathrm{v}$ pohybu, který je $\mathrm{v}$ podmínkách modernity potlačovaný a zastíraný. Z perspektivy nomádství je každý člověk tvořen soustavou vztahů vázanosti a vyvázanosti, přitahování

6 Jednotné a autonomní individuum odpovědné za své jednání a za svou biografii se ukazuje být stejně tak abstraktním a efemérním konceptem, jakým jsou mocensky prosazované společně sdílené národní symboly mas. Právě v tomto smyslu píše Maffesoli (1996a) o rozkladu moderního individualismu. Představa jedince jako jednotného, racionálního a autonomní člověka je na ústupu, autonomní jedinec není už tak přesvědčivým normativním ideálem a ikonou jako v poválečném období. 
a odpuzování. Maffesoli (2002) upozorňuje na to, že nomádství nových kmenů s sebou nese fundamentální relativizaci individualismu i moderní ideologie práce. Jinak řečeno, v současnosti se již rozpadává normativní diskurs, podle kterého se člověk musí snažit o seberealizaci formou pracovního úspěchu. Pokud se budeme snažit vysvětlit různé podoby života v pohybu ekonomickými motivy, zůstaneme v zajetí moderní ideologie práce. Diskurz založený na ekonomické imaginaci jednak normativně vyzdvihuje práci jako jediný přijatelný cíl života jedince, jednak považuje motivační pozadí práce za jedinou představitelnou, základní motivační sílu jednání lidí. Podobně jako diskurzu ideologie práce vzdorují poutě do Říma či Compostelly, překračuje užitné, ekonomické pojetí světa také cestování mladých Evropanů a Američanů do Indie. Př́itomnost života v pohybu v podobě nomádství nových kmenů je důkazem toho, že kulturní identity vznikající vykročením z koloběhu každodenního života práce hrají i v soudobé společnosti zásadní roli. Domov, domovina či domácnost a jim odpovídající hospodářský prostor, tj. místo kultivované naší každodenní prací, není jedinou formou místa formování kulturní identity. Domov není jedinou formou místa, jež zprostředkovává společenství soudržnosti.

\section{Závěr}

Putování i potulování se jsou nezpochybnitelně součástí sociální reality. Klíčovým však je, jak na tyto fenomény nahlížejí dominantní instituce a jak tyto podoby života $\mathrm{v}$ pohybu interpretujeme $\mathrm{z}$ hlediska sociálních věd. Jestli jsou považovány za následováníhodný životní vzor, nebo spíše za deviaci, úchylku. Jestli je nomádství používáno jako konceptuální model orientace ve světě a porozumění světu, nebo je-li nomádské myšlení, myšlení v diskurzu nomádství spíše vnímáno jako nevhodný model poznávání skutečnosti. Jestli dominantní instituce a diskurzy sociálních věd ustavují putování a potulování jako správné životní formy a jestli uznávají nomádské myšlení jako smysluplné či nikoliv.

Uznání ambivalence světa pomocí konceptuálních modelů putování a potulování přitom neimplikuje, že nomádství je podstatou sociálního života na úkor usazenosti. Relativizace nostalgie po domovu a přijetí nomadských identit není snahou nahradit esenci usazenosti esencí potulování. Záměrem je pouze zdůraznění ambivalence: dvojí přítomnosti zakořeněnosti a pohybu. Tuto ambivalenci sociální reality umožňuje uchopit Maffesoliho (2002) pojem ,dynamické zakořeněnosti“, který poukazuje na to, že i když vždy pocházíme z nějakého místa, toto místo získává význam v procesu jeho reálného či fiktivního popření a překonání. Dynamická zakořeněnost ř́ká, že bez odchodů neexistují návraty, bez pohybu neexistují místa, která jsou z hlediska našich identit formativní.

Představa místa formujícího kulturní identity a prostředkujícího společenství sounáležitosti v podobě domova předpokládá sdílení světa každodennosti, který tvoří pozadí vzájemných vztahů a sociálního jednání. Místo, kde je naše sdílená identita zakořeněna, a to, co sdílením domova sdílíme „my všichni“, je podle této perspektivy totalitou životního světa každodennosti. ${ }^{7}$ Alternativu tohoto pojetí, jež byla přiblížena Schützovým důrazem na sdílení světa každodennosti, můžeme nacházet v Durkheimově perspektivě, jež upřednostňuje rituální a emocionální aspekty sdílení dílčích světů významů (Durkheim 2002, Alexander a Smi- 
th 2005, Maffesoli 1996b). Jinak řečeno, durkheimovská perspektiva klade při výkladu formování kulturních identit důraz spíše na ritualizovanou podobu prrítomnosti na specifických místech než na žitou přítomnost na sdíleném místě každodennosti. V tomto smyslu není žitá přítomnost na sdíleném místě každodennosti jedinou podmínkou formování společenství soudržnosti a sdílených kulturní identit, jež váže subjekty k tomuto společenství. Není to pouze sdílená každodenní přítomnost na určitém místě, ale také periodická přítomnost na místech generujících sdílené, např́iklad estetické či religiózní, zkušenosti, jež vytváří situaci sdílení identity a společenství sounáležitosti. Je to jakási miniaturní a dočasná totalita praktického jednání, která supluje sdílenou totalitu každodenního jednání. Teoretickým předpokladem této alternativy je model kulturní komunity, která už nežije v jedné vesnici, nesdílí místo a žitou př́ítomnost každodennosti, sdílí ale mýty, rituály, praktiky a zkušenosti místa, kde se její příslušníci scházejí, aby prožili událost společného shromáždění.

\section{Literatura}

Ahmed, S. 1999. „Home and Away: Narratives of Migration and Estrangement.“ International Journal of Cultural Studies, 2: 329-347.

Alexander, J. C.; Smith, P. 2005. The Cambridge Companion to Durkheim. Cambridge: Cambridge University Press.

Anderson, B. 1991. Imagined Communities: Reflections on the Origin and Spread of Nationalism. London: Verso.

Anderson, B. 1994. „Exodus.“ Critical Inquiry, 20: 314-327.

Appadurai, A. 1988. „Putting Hierarchy in its Place.“ Cultural Anthropology, 3: 36-49.

Appadurai, A. 1997a. „Disjuncture and Difference in the Global Cultural Economy.“ In Modernity at Large. Cultural Dimension of Globalization. Minneapolis: University of Minnesota Press, s. 27-47.

Appadurai, A. 1997b. „Global Ethnoscapes: Notes and Queries for a Transnational Anthropology.“ In Modernity at Large. Cultural Dimension of Globalization. Minneapolis: University of Minnesota Press, s. 48-65.

Appadurai, A. 1997c. ,The Production of Locality.“ In Modernity at Large. Cultural Dimension of Globalization. Minneapolis: University of Minnesota Press, s. 27-47.

Augé, M. 1995. Non-places: Introduction to the Antropology of Supermodernity. London. Verso.

Bash, L. A kol. 1994. Nations Unbound: Transnational Projects, Postcolonial Predicaments, and Deteritorialized Nation-States. London: Routledge.

Bauman, Z. 1993. Modernity and Ambivalence. Cambridge: Polity.

Bauman, Z. 1999. Globalizace. Praha: Mladá fronta.

Bell, D. S. A. 2003. „Mythscapes: Memory, Mythology, and National Identity.“ British Journal of Sociology, 54: 63-81.

Berger, P. L.; Luckmann, T. 1996. Sociálni konstrukce reality. Brno: CDK.

I když Schutz klade důraz na existenci ostatních světů, tyto světy jsou pro něho spíše ohraničenými realitami významů, jakýmisi ostrůvky v moři každodennosti (Berger a Luckmann 1999, Schutz a Luckmann 1973). 
Brettell, C. 2000. „Theorizing Migration in Anthropology: The Social Construction of Networks, Identitites, Communities and Globalscapes.“ In C. Brettell, J. Hollifield (eds.) Migration Theory: Talking Across Disciplines. New York: Routledge, s. 97-135.

Brettell, C. 2003. Anthropology and Migration: Essays on Transnationalism, Ethnicity and Identity. Oxford: Altamira Press.

Brettell, C.; Hollifield, J. 2000. „Introduction to Migration Theory: Talking Across Disciplines.“ In C. Brettell, J. Hollifield (eds.) Migration Theory: Talking Across Disciplines. New York: Routledge, s. 1-26.

Brubaker, R. 1996. Nationalism Reframed: Nationhood and National Question in the New Europe. Cambridge: Cambridge University Press.

Castles, S.; Davidson, A. 2000. Citizenship and Migration. Globalization and the Politics of Belonging. London: Macmillan.

Clifford, J. 1988. The Predicament of Culture: Twentieth Century Ethnography, Literature and Art. Cambridge, Mass: Harvard University Press.

Clifford, J. 1997a. ,Travelling Cultures.“ In Routes: Travel and Translation in the Late Twentieth Century. Cambridge, Mass: Harvard University Press, s. 17-47.

Clifford, J. 1997b. „Diasporas.“ In Routes. Travel and Translation in the Late Twentieth Century. Cambridge, Mass: Harvard University Press, s. 244-277.

Deleuze, G., Guattari, F. 1992. A Thousand Plateaus: Capitalism and Schizophrenia. London: Continuum.

Durkheim, E. 2002. Elementární formy náboženského života. Praha: Oikúmené.

Faist, T. 2000. „Transnationalization in International Migration: Implications for the Study of Citizenship and Culture." Ethnic and Racial Studies, 23 (2): 189-222.

Foucault, M. 1998. „Nietzsche, Genealogy, History.“ In Aesthetics, Method and Epistemology. London: Penguin, s. 369-391.

Gans, H. 1962. The Urban Villagers. New York: Free Press.

Giddens, A. 1990. The Consequences of Modernity. Cambridge: Polity.

Glick Schiller, N.; Fouron, G. E. 2001. Georges Woke Up Laughing: Long-Distance Nationalism and the Search for Home. Durham: Duke University Press.

Guarnizo, L. E.; Smith, M. P. 1998. „The Locations of Transnationalism.“ In L. Guarnizo, E. Smith, P. Michael (eds.) Transnationalism from Below. New Brunswick. Transaction, s. 3-34.

Guarnizo, L. E. 2001. „On Political Participation of Transnational Migrants: Old Practices and New Trends.“ In G. Gerstle, J. Mollenkopf (eds.) E Pluribus Unum? Contemporary and Historical Perspectives on Immigrant Political Incorporation. New York: Russell Sage, s. 231-263.

Gupta, A.; Ferguson, J. 1997. „Beyond ,Culture“: Space, Identity and the Politics of Difference." In A. Gupta, J. Ferguson (eds.) Culture, Power, Place: Explorations in Critical Anthropology. Durham: Duke University Press, s. 33-51.

Hannerz, U. 1980. Exploring the City: Inquiries toward an Urban Anthropology. New York: Columbia University Press.

Hannerz, U. 1992. Cultural Complexity: Studies in the Social Organization of Meaning. New York: Columbia University Press.

Hannerz, U. 1998. Transnational Connections. London: Routledge. 
Heisler, B. S. 2000. ,The Sociology of Immigration: From Assimilation to Segmented Integration, From American Experience to the Global Arena." In C. Brettell, J. Hollifield (eds.) Migration Theory: Talking Across Disciplines. New York: Routledge, s. 77-96.

Kearney, M. 1995. „The Local and the Global: The Anthropology of Globalization and Transnationalism." Annual Review of Anthropology, 24: 547-565.

Maffesoli, M. 1996a. The Time of the Tribes: The Decline of Individualism in Mass Society. London: Sage.

Maffesoli, M. 1996b. The Contemplation of the World. Figures of Community Style. Minneapolis: Minnesota University Press.

Maffesoli, M. 2002. O nomádství: Iniciační toulky. Praha: Prostor.

Malkki, L. H. 1995. „Refugees and Exile: From ,Refugee Studies“ to the National Order of Things, “' Annual Review of Anthropology, 24: 495-523.

Malkki, L. H. 1997. „National Geographic: The Rooting of People and Territorialization of National Identity Among Scholars and Refugees.“ In A. Gupta, J. Ferguson (eds.) Culture, Power, Place: Explorations in Critical Anthropology. Durham: Duke University Press, s. $52-74$.

Mallett, S. 2004. „Understanding Home: a Critical Review of Literature.“ The Sociological Review, 52: 62-89.

Massey, D. S. A kol. 1998. Worlds in Motion: Understanding International Migration at the End of Millenium. Oxford: Calderon Press.

May, J. 1999. Nomadic Citizenship: The Performance of Citizenship. Minneapolis: Minnesota University Press.

Meyrowitz, J. 1985. No Sense of Place. The Impact of Electronic Media on Social Behaviour. New York: Oxford University Press.

Morley, D.; Robins, K. 1995. Spaces of Identity: Global Media Electronic Landscapes. London: Routledge.

Ricoeur, P. 1992. Oneself as Another. Chicago: Chicago University Press.

Rosaldo, R. 1993. Culture and Truth: The Remaking of Social Analysis. Boston: Beacon.

Rushdie, S. 1995. Midnight's Children. London: Vintage.

Schutz, A.; Luckmann, T. 1973. The Structures of the Life-World. Evanston: Northwestern University Press.

Schütz, A. 2004. „A hazatérő (Der Heimkehrer).“ In G. Biczó (ed.) Az idegen: Variációk Simmeltöl Derridáig (Cizinec: Variace od Simmela k Derridovi). Debrecen: Csokonai Kiadó, s. 80-91.

Smith, A. D. 1986. The Ethnic Origins of Nations. Oxford: Blackwell.

\section{Autor}

Csaba Szaló působí na Katedře sociologie Fakulty sociálních studií Masarykovy univerzity. Zabývá se sociologií kultury. Jeho výzkumné aktivity se zaměřují na proces kulturní asimilace a sociální konstrukce etno-národních identit. Je spolueditorem knihy Mozaika v re-konstrukci: Formování sociálních identit v současné střední Evropě (Brno: MPÚ 2003). Kontakt: szalo@fss.muni.cz 